IRA-International Journal of Management \&

Social Sciences

ISSN 2455-2267; Vol.16, Issue 01 (Jan.-March, 2020)

Pg. no. 1-22.

Institute of Research Advances

http://research-advances.org/index.php/RAJMSS

QUARTERLY

$2 \begin{aligned} & \text { Institute of } \\ & \text { Research } \\ & \text { Advances }\end{aligned}$

\title{
Conditional Efficiency of Official Development Assistance (ODA) on Economic Growth in Sub-Saharan Africa
}

\author{
Ladifatou GACHILI NDI GBAMBIE Ph. ${ }^{1}$, Ousseni MONGBET ${ }^{2 \#}$ \\ ${ }^{1}$ University of Yaounde II, Centre d'Etude et de Recherches en Economie et Gestion (CEREG), PO \\ BOX: 1365 Yaounde - Cameroon. \\ ${ }^{2}$ Ph.D Student, University of Yaounde II, Health Economics Research and Evaluation for \\ Development Results Group (HEREG), PO BOX: 1365 Yaounde - Cameroon.
}

\# corresponding author

Type of Work: Peer Reviewed.

DOI: http://dx.doi.org/10.21013/jmss.v16.n1.p1

How to cite this paper:
Ladifatou GACHILI NDI GBAMBIE, Ousseni MONGBET. (2020). Conditional Efficiency of Official
Development Assistance (ODA) on Economic Growth in Sub-Saharan Africa. IRA-International
Journal of Management \& Social Sciences (ISSN 2455-2267), 16(1), $1-22$.
doi:http://dx.doi.org/10.21013/jmss.v16.n1.p1

(C) Institute of Research Advances.

(cc) Br-no

This work is licensed under a Creative Commons Attribution-Non Commercial 4.0 International License subject to a proper citation to the publication source of the work.

Disclaimer: The scholarly papers as reviewed and published by the Institute of Research Advances (IRA) are the views and opinions of their respective authors and are not the views or opinions of the IRA. The IRA disclaims of any harm or loss caused due to the published content to any party.

Institute of Research Advances is an institutional publisher member of Publishers International Linking Association Inc. (PILA-CrossRef), USA. The institute is an institutional signatory to the Budapest Open Access Initiative, Hungary advocating the open-access of scientific and scholarly knowledge. The Institute is a registered content provider under Open Access Initiative Protocol for Metadata Harvesting (OAI-PMH).

The journal is indexed \& included in WorldCat Discovery Service (USA), CrossRef Metadata Search (USA), WorldCat (USA), OCLC (USA), Open J-Gate (India), EZB (Germany) Scilit (Switzerland), Airiti (China), Bielefeld Academic Search Engine (BASE) of Bielefeld University, Germany, PKP Index of Simon Fraser University, Canada. 


\begin{abstract}
Sub-Saharan Africa (SSA) countries have benefited for more than fifty years from international aid in the form of loans and/or donations. Nevertheless, they seem not to benefit from these massive financial resources (ODA) they receive because their economic and social situation is not very good. This study aims to assess the impact of ODA on economic growth in SSA and to see if its effect on growth is conditioned by the quality of the economic policy. The estimates are conducted on a dynamic panel of twenty-three SSA countries running from 1985 to 2014. With macroeconomic data from the World Bank's CD-ROM (World Development Indicators, 2015), the Generalized Method of Moment (GMM) system from Blundel and Bond (1998) was used. The results show that the impact of ODA on growth is not significant. Subsequently, when squared aid (ODA2) is included in the estimate, ODA becomes significant, meaning that a substantial amount of assistance is required to be effective in raising the economic growth rate of the SSA countries.
\end{abstract}

In addition, the effectiveness of ODA is conditioned by the quality of the economic policy. This seems to be bad in SSA, hence the negative impact of the aid on economic growth.

Keywords: Sub-Saharan Africa (SSA), Official Development Assistance (ODA), Conditioned Efficiency, Economic Growth, GMM System

\title{
1. INTRODUCTION
}

The first call in the history of humanity to international assistance was launched by Evsey Domar in his article "Capital Expansion, Rate of Growth, and Employment" in 1946, after the Second World War. This historic call will give birth to an international development aid policy whose main objective was to fight against poverty in the world. Since then, the United States has taken the lead in the policy of assisting countries in difficulty by setting up in 1947, through President Truman, the "European Recovery Program", better known under the name of the Marshall Plan ${ }^{1}$. Thus, fifteen billion dollars will be transferred in four years to Europe for its reconstruction, or $1.16 \%$ of the US overall GDP over this period (Charnoz and Severino, 2007).

At the beginning of the 1960s, with the wave of African independence, ODA took off with the proliferation of donor countries (including the USSR and China) and beneficiaries. As a result, for more than 50 years, international aid in the form of loans and/or grants has financed many projects and programs in countries in need. The countries of Eastern Europe, Asia, Latin America, Africa and those from the former USSR have benefited from assistance in several areas: educational, medico-social, economic, infrastructural and even cultural. SSA countries have not remained on the sidelines of this international solidarity. Nevertheless, they do not seem to benefit from these massive financial resources (ODA) they receive because their economic and social situation is not very good. The increasing concentration of global poverty in SSA is worrisome. In fact, according to the World Bank (WB, 2016) report on poverty, in 1990, East Asia accounted for half of the poor, compared to around $15 \%$ in SSA. In 2015, the situation was virtually reversed, with SSA concentrating half of the world's poor, compared to about $12 \%$ in East Asia. These statistics only confirm the finding of the United Nations Development Program (UNDP, 2001) that SSA remains plagued by rising poverty.

On the other hand, SSA has experienced relatively dynamic growth over the last decade and has remained the second most dynamic region in the world according to the International Monetary Fund (IMF, 2014). The average growth of real GDP from 2009 to 2013 is 5.1\% and is lower than the one obtained between 2000-2008 which is $6.6 \%$. However, these economic growth rates are still insufficient to eradicate poverty and ensure

${ }^{1}$ On June 5, 1947 US Secretary of State George C. Marshall offers economic and financial assistance to all European countries. They will be sixteen to accept the European Recovery Program (ERP) or Marshall Plan. 
sustainable development and even growth, since according to the United Nations 2014 report on Africa's development, in order to significantly reduce poverty, Africa is expected to have an average growth rate in the medium and long term of 7\%. Does ODA have an impact on economic growth in SSA? Would its effectiveness on growth be conditioned by the quality of economic policy?

\section{ODA AND GROWTH: A REVIEW OF THEORETICAL AND EMPIRICAL LITERATURE}

ODA has been the subject of considerable debate both theoretically and empirically by several authors. On the one hand, it seems wise to identify the major theories of ODA and on the other hand to elucidate the empirical work on the relationship ODA and economic growth.

\subsection{Theories of ODA: Evolution and Criticism}

The theoretical importance of ODA for an economy in need of financing goes back to the work of Harrod (1939, 1942) and Domar (1946) who developed the "Financing Gap" model.

\section{- Theory of Harrod (1939, 1942) and Domar (1946).}

Harrod and Domar believe that for an economy with low savings, growth will be so low. To increase the rate of income growth, it is necessary and sufficient to increase the investment rate and therefore the savings rate. In their analysis, when domestic savings are insufficient, it is possible to deduce the amount of foreign savings needed to achieve an investment rate consistent with the desired growth rate.

Indeed, their model seems to provide a clear explanation of differences in growth between economies. The production function has complementary factors (capital and labor). The supply of labor is always assumed to be surplus in developing countries, regardless of the category of labor considered and therefore the limiting factor in practice is the capital factor. Poor countries are characterized by low income and thus a low savings rate. Low savings in poor countries constrain investment and lead to low capital stock. Their economic growth rate is therefore condemned to remain low. They are thus closed in the vicious circle of poverty: it is the underdevelopment trap that the authors represented by the graph below:

Figure 1: The poverty trap in the Harrod-Domar model

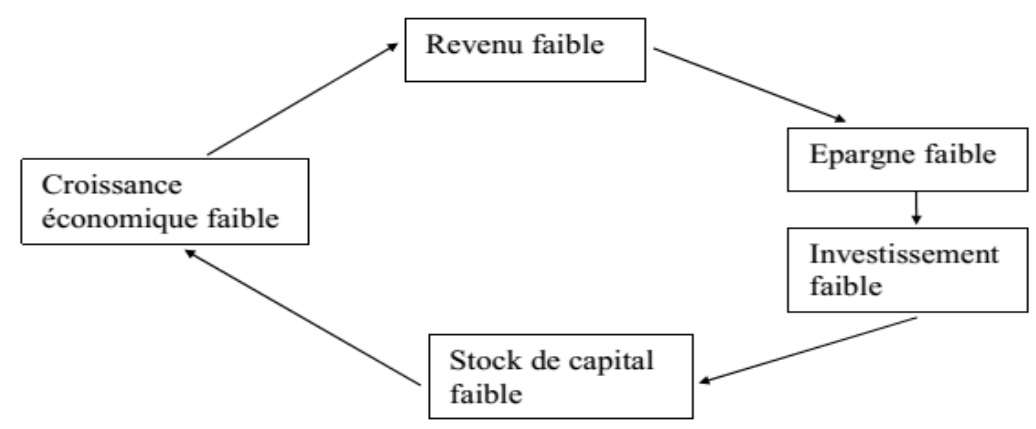

Source: Amewoa (2008: 73)

The role of savings is therefore decisive for the objective of economic growth. When an economy wants to get out of the trap, it must increase its savings to cross the threshold of underdevelopment. In the case of poor countries, this increase is impossible because of the low income, hence the need for the ODA (external savings 
contribution) to fill the savings gap in these economies. The model makes it possible to determine the missing investment in an economy to reach a growth rate initially set as a target. This determines the need for external assistance from the economy by setting an objective growth rate corresponding to the natural growth of the labor supply.

This economic representation of growth is based on a quantitative and financial approach: to achieve a given growth objective, it would be sufficient to have an adequate investment target and the purpose of the aid is to close the gap between available savings and this investment target is the model of the financing gap, that is to say, the lack of financing of the economy. The delay of a country is explained by a lack of capital and catching up is possible. This interpretation is modeled in the following form: The Q production capacity is linked to the capital stock and is given by a simple relation of the type :

$\mathrm{Q}=\mathrm{a} \mathrm{K}$ or $\mathrm{Q}=\mathrm{a} \mathrm{K}+\mathrm{b}$ where $\mathrm{a}$ is the inverse of the average capital coefficient in the first specification and marginal in the second. It is the ratio between the increase of production and the increase of the stock of capital or ICOR (incremental capital-output ratio). The direction of determination is the rate of growth of the economy g (for which we choose an exogenous value g) towards investment. An increase in DQ production will, therefore, require an investment I = DQ / a. This investment needed to achieve the growth set as "goal" will then be compared to local savings. It is determined from income by an average or marginal propensity to save. The potential difference between investment and local savings (gap) is supposed to be financed by external aid. A variant of the financing-gap model, but which is very close to it, is the two-gap model of Hollis Chenery and Alan Strout (1966).

\section{- Double deficit model}

Inspired by the work of Harrod and Domar, Strout Alan and Chenery Hollis ${ }^{2}$ (1960) develop a new theoretical model called the "double deficit model" or Two Gap Model which puts forward two constraints: an insufficiency of domestic savings first and a deficiency currency later. According to these two authors, in the very early stages of industrial growth, savings may be the main constraint on the rate of domestic capital formation. Once industrialization is well underway, the main constraint may no longer be domestic savings per se, but the availability in the currency required to import capital goods, intermediate goods and perhaps even materials. first used as industrial inputs. The foreign exchange deficit can thus surpass the savings deficit as the main constraint of development. Chenery and Strout advocate, in order to solve this double deficit problem, to borrow foreign exchange and / or obtain it by increasing its exports. The model starts from the global balance of jobs and resources, which is written in national accounts when the economy is open with equality:

$\mathrm{I}-\mathrm{S}=\mathrm{M}-\mathrm{X}$.

$\mathrm{M}$ refers to imports and $\mathrm{X}$ exports. The equation reflects the fact that the domestic savings deficit (investmentsavings) is equal to the external deficit (imports - exports). But this balance is ex-post. Both deficits may be unequal ex-ante, which affects the rate of economic growth. To calculate the optimal amount of aid, it is sufficient to first calculate the level of investment required to achieve the targeted growth rate and then the difference between the required investment and the available reserves at the national level.

\section{- Big Push Theory}

By heavily financing investment in poor countries through international development assistance, countries falling into the poverty trap described by Harrod and Domar can begin their process of economic growth and escape the trap. Economic growth can then be self-sustaining; hence the Big Push.

\footnotetext{
${ }^{2}$ Listed by Toussaint (2014)
} 
Rosenstein-Rodan (1943) developed the Big Push theory for an economy in need of financing. In essence, the author emphasizes that massive inflows of external capital must enable poor countries to finance their investments and to burn some steps prior to take-off. The key idea is that a large number of industries that are mutually supportive of each other's customers must be created simultaneously so that demand exists and is sufficient. The state ensures not only the promotion of industries but must also ensure that the economy as a whole benefit from external effects. Nurkse (1953) emphasizes the risk of diverted aid to consumption instead of production.

For Rosenstein-Rodan (1943, 1961) and Regnar Nurkse (1953), the problem of poor countries is much deeper. They would be locked in a vicious circle characteristic of underdevelopment. A small increase in investment can not prevent them from the difficulties of economic growth. Aid needs to be high enough to break the cycle of poverty. Only then can we eliminate poverty in the world. Indeed, according to Rosenstein-Rodan (1943, 1961), there is a given threshold of capital per capita below which a country is condemned to remain poor. This is the threshold of the underdevelopment trap. In order for them to grow and develop, international aid must enable them to boost their capital stock per capita beyond this threshold (poverty trap threshold). This is how Rosenstein-Rodan (1961) proposes a big push for all poor countries. That is to say, they are given rapid and massive aid, which according to the author, is the only way to eliminate poverty in the world.

Later, Hirschman (1964) casts doubts on the possibility of developing an economy through massive and simultaneous foreign investments in all sectors, without improving the qualifications of the populations. At this level, it raises the low impact of foreign capital on economic growth if the number of skilled people in the assisted country is insufficient. He emphasizes unbalanced growth because, for him, foreign aid increases investment and production capacity. If the economy grows to employ enough of this capacity, the additional income created by the increase in that capacity will lead to an increase in savings, and therefore new investment.

Ridell (1987) in turn synthesizes the theories that marked the post-war period. He argues that aid has become an important aspect of international relations since the 1950s. Aid theorizing emerged at the same time on the paradigm that development requires intervention and that additional resources lead to a higher level of development. : it is the takeoff or big push theory, identification of the deficits characteristic of the developing countries in savings and investments, incapacity of import, qualified labor force and in foreign currencies. The different theories devoted to aid have been strongly challenged.

\section{- Criticism of ODA theories}

The theories of Financing Gap, Big Push, and the Two Gap Model have been heavily criticized by some of the literature. Indeed, as Easterly (1999) points out, the Harrod and Domar model are based on two assumptions: that of the linear relationship between investment and growth, and the second which states that aid is used to finance investment and not consumption. It puts deeply into question the two assumptions on which the theory is based.

Easterly (2005) criticizes the model of Harrod and Domar that he deems not conform to reality. The financing gap model such as the Big Push or double deficit model does not take into account incentives in recipient countries as well as other factors such as the quality of institutions, the political atmosphere of aid; and assume that the aid received is totally dedicated to financing the investment. For its part, Gabas (2005) considers that the need for financing for the development of a country is not programmable, let alone calculable on the basis of a sum of microeconomic achievements in terms of investments, be they public or private. He stressed that developed economies have never used such reasoning to plan financial needs for their own development. Similarly, the use of external contributions will limit local savings: "As long as the cost of aid (for example, the 
interest rate on external loans) is lower than the marginal increase in capital and from production, a country will have an interest in borrowing as much as possible and substituting foreign borrowing for domestic savings. " The foundations of these models are therefore weak in that one would theoretically expect to find an inverse relationship between foreign aid and domestic savings. In addition to these criticisms of the ODA's theories, the latter has also been criticized by Marxists and Liberals.

\section{- Liberal Critique of ODA}

According to liberal critics, ODA can not promote economic growth in the South. On the contrary, it deteriorates it by distorting the rules of the market and economic liberalism. Defenders of this trend (Bauer, Friedman, Griffin, Berg, and Mosley among others) believe that far from solving a humanitarian crisis, food aid can only aggravate food insecurity. In fact, large quantities of food supplies in the event of a humanitarian crisis spontaneously increase the supply of the products in question. This results in lower prices at the local level: ceterisparibus, this discourages investment and local production of food and therefore a decline in production activity in the agricultural sector which ultimately results in a decline in economic growth. They also believe that the food abundance created by food aid encourages recipient countries to adopt policies that are not conducive to local production. As a result, economic activity is reduced in the country and the increase in dependence on the outside is also noted (Bauer, 1987). With regard to international financial assistance, Friedman (1958) argues that it allows developing country leaders to maintain certain unprofitable and harmful sectors of private sector development in the state's portfolio. State-owned enterprises often financed with international aid have low or even negative returns. Very often, aid is used to create activities that the private sector has deliberately refused to fund because of low returns. Aid thus channels the resources of the recipient country towards unproductive or inefficient sectors and investments. He added that, in financial and monetary terms, the aid creates distortionary effects on interest rates.

Another mischief of international aid is the increase in corruption and bureaucracy. The domestic workforce is moving more towards the growing public sector and crowding out the private sector (Bauer, 1972). Public spending increases with aid and crowds out domestic savings (Mosley, 1996). International aid is, in the best of cases, of zero or almost no effectiveness in alleviating the misery of the Third World or in facilitating development in poor countries (Bauer 1984, Berg 1996). Alongside liberal-inspired critics, there are also those inspired by Marxism.

\section{- Marxist approach}

This so-called mainstream approach of rejection of development or anti-development opposes the WB and IMF view that international aid is the policy for promoting economic growth in poor countries and defeating poverty. The promoters of this trend (Dumont, Toussaint, Mandel to name only a few) consider international aid as well as all development policies as serving above all the cause of the rich countries. ODA is seen here as a powerful channel through which industrialized countries continue to dominate developing countries despite their political independence. Treillet (2003) sums up their proposition in this way: " development both on the theoretical level (system of thought, objectives) and on the level of the strategies implemented (aid, globalization, ...) did not constitute the societies of Africa, Asia, and Latin America since their independence, a new avatar of the domination of the industrialized countries and the Westernization of the world on all levels (economic, social, cultural ...)".

The "anti-developmentalists" denounce the "development" and its practices which they describe as "disasters". The Westerners, nostalgic of the colonial period and anxious to always control the other parts of the world set up the ODA. Today it is the disguised manifestation of the egoism of the most well off and a new 
means of their interference in the affairs and life of the Third World countries. According to anti developmentalists, ODA exists only for the sake of sustaining Western domination. The introduction of international aid, by increasing the intervention of Western countries in the countries of the South, had the initial goal of stopping the progress of the Communists and keeping control of the former colonies. In addition, the aid serves as a justification tool for intervention in developing countries, aimed above all at the interest of the donor.

In addition, international aid promotes unequal trade that enriches the industrialized countries to the detriment of the South. Through trade relations and international aid that generates debt, Western countries take more financial resources from developing countries than they get from them. Gigantic debt is a sure way for rich countries to keep poor countries in their sphere of influence and alienation. Foreign aid can not contribute substantially to developing countries. On the contrary, she is able to delay it.

Faced with the pessimism of anti-developmentalists, several contributions will condition the effectiveness of aid to good governance and healthy institutions. Assisted countries must then have good institutions so that aid improves the well-being of their populations. In this regard, the Paris Declaration advocates a new form of North-South cooperation that aims to increase the effectiveness of external assistance by prescribing greater national ownership, alignment with national strategies and harmonization of practices and policies donor actions (OECD and WB, 2005). Obtaining such objectives requires a better institutional capital endowment as well as a better match between institutions brought by the donors and those accumulated in the assisted country.

\subsection{Impact of ODA on Growth: An Empirical Review of the Literature}

A large number of empirical studies on aid effectiveness examine the impact of ODA on economic growth. The conclusions of these studies are not unanimous in the literature.

\subsubsection{ODA: the engine of economic growth}

Several studies highlight the crucial role of ODA in promoting economic growth and ultimately development. In the first row, Papenek (1973) and Levy (1988) showed that the aid not only stimulated growth through an increase in savings and capital stock, but also contributed to an improvement in productivity workers through investment in education and public health. The works of Papenek and Levy are certainly interesting; however, they cover only the period from 1968 to 1982.

Nyoni (1997) examines the impact of foreign aid on macroeconomic variables such as the real exchange rate, export performance, government spending, investment and growth. Using cointegration techniques and the error-correction model, he argues that the increases in aid have been accompanied by record growth in domestic investment in Tanzania. Nyoni (1997) uses a time series, while our analysis is based on panel data. The use of panel data makes it possible to work on samples of small size (in the temporal dimension) by increasing the number of available data (in the individual dimension), thus reducing the probability of facing structural breaks and overcoming the problem of low power tests in a small sample.

Similarly, Gomanee and al. (2002) identify investment as the channel through which ODA affects growth. They use panel data from 25 SSA countries over the period 1970 to 1997 and show that ODA has a positive and significant effect on growth. On average, each one percentage point increase in the ODA / GDP ratio contributes to the growth of a quarter of a percentage point. They state that the weak growth noted in Africa should not be attributed to the inefficiency of ODA. At the same time, in order to highlight the impact of ODA on the growth of 48 developing countries over the period 1970 to 1998, Moreira (2005) used the Generalized Method of 
Moments from Arellano and Bond (1991). His study reveals that ODA has had a positive impact on economic growth. In addition, the author argues that ODA has less impact on growth in the short run than in the long run. He concludes therefore that time offsets in the aid-growth relationship must be taken into consideration.

Moreira (2005), as well as Gomanee and al. (2002), did use panel data, but they used the Generalized Method of Moments in first-difference from Arellano and Bond (1991). The GMM first difference estimator gives biased results in the finished samples when the instruments are weak or when persistent variables are present. The bias affecting the Arellano and Bond estimator (1991) and leading to an underestimation of the autoregressive coefficient would be according to Blundel and Bond (1998), corrected by the system estimation.

Similarly, Sachs (2005) argues that to get Africa out of its poor development, the amount of aid must be substantially increased. According to the author, the aid granted to Africa is negligible because there is a chronic lack of funding by donors. Sachs estimated that in 2006 alone, 135 billion dollars were needed and 195 billion in 2015, to hope to reduce poverty in Africa.

Fielding and al. (2006), for their part, say that aid has a positive influence on the MDG variables (access to water, education, etc.) but is not very favorable to the poor since the subgroup of the poorest does not seem to be the main beneficiary. Fielding et al. just as Sachs relies solely on facts to reach their conclusions.

Khan (2006) used the Pooled Estimated Generated Least Squares (Pooled EGLS) method and showed that investment is considered one of the channels through which ODA affects economic growth. According to him, the volatility of aid has a negative impact on domestic private investment in the CEMAC countries, but if we take into account their export earnings (through an interactive variable), this effect is mitigated. The dependence of these countries on export earnings rather than aid makes the volatility of aid inconsistent. More attention should be given to export earnings that are more volatile and harmful than aid flows. Khan's method of analysis, based on generalized least squares, does not make it possible to obtain efficient estimators of such a panel model.

Tarp (2009) shows that the effect of foreign aid on growth is positive. The long-run elasticity of growth relative to the share of aid in GDP is around 0.20. This is consistent with the view that foreign aid stimulates aggregate investment and also contributes to growth productivity despite the fraction of aid allocated to consumption. Aid, he says, has been and remains an important instrument for strengthening development prospects for poor nations.

In order to show the impact of ODA on Niger's economic growth, Nafiou (2009) used an error-correction model for long series. He concludes that ODA, better than school variables, has a positive and significant impact on real GDP in the long run. However, it uses control variables that could be qualified as irrelevant, such as the average annual rainfall height in determining the aid's impact on growth.

Nafiou's assertion was supported by Joannidis (2010) who states that with its ups and downs, successes and failures, ODA has long governed relations between rich and poor countries. Today, it is at least dogged by the support of the private sector as the engine of growth.

Severino and Ray (2010) attempt to change the look of aging Europe on SSA. For them, the latter that has been described as a "bad party" is running. We must not refuse to see the signs of its metamorphosis because it becomes an actor of its destiny on the world stage. In a book published with the collaboration of Debrat (2010), Severino protests against the words of Dambisa. He considers that a point of balance is to be found between two "compassionate" speeches concerning ODA, according to which it alone is capable of generating economic take-off and those who reject it in its current form. Severino is particularly against "misconceptions" 
including the ineffectiveness of aid, the responsibilities of the IMF and the WB in the bankruptcy of southern countries and so on.

Whether Joannidis (2010), Severino and Ray (2010) or Severino and Debrat (2010), their reasoning remains deductive. Guloba and al. (2010) highlighted the impact of Chinese aid on Uganda's economy. Their study shows that Chinese aid has an impact on the economic and social well-being of the Ugandan population. The lack of econometric analysis confirms his claims.

Unlike previous authors who value ODA, many believe that it does not promote the growth of developing countries.

\subsubsection{ODA: hindering economic growth}

The report of the DAC President of 1967 already mentioned the failures of aid policies in the fight against poverty (Gabas and Sindzingré, 1996).

Hayter (1971) also argues in his book "Aid as imperialism" that the assistance provided by the WB and the OECD countries serves primarily the interests of Western countries and their transnational companies. ODA favors the control of the resources of developing countries by the ruling class of Western countries. Aid helps keep poor countries in a dependency relationship with the West.

Bauer (1976) argues that aid has expanded government bureaucracies, perpetuated poor governance, enriched elites in poor countries, or simply wasted. As an illustration, he notes the rapid spread of poverty in Africa and South Asia despite three decades of aid and points out that countries that have received substantial aid (DRC, Haiti, Somalia) have had disastrous results. According to him, aid programs must be dramatically reformed, substantially reduced or simply eliminated.

Barro (1990), just as many researchers argue the opposite to that of Levy and Papenek (1973). The results of his model reveal the negative relationship between aid and growth. Other critics have pointed out that the market, private investment and commercial lending are more apt to stimulate growth. Moreover, Jepma (1991 and 1996) argues that tied aid, favored by bilateral donors, primarily serves the interests of private firms in donor countries and has little relation to development objectives. Boone's (1996) work has shown that aid would increase public consumption by maximizing, among other things, the weight of the utility of public expenditure policies.

In the same vein, Berg (1997) concludes that more aid tends to increase, the more negative the effects become and become destabilizing in countries where aid reaches 5\% of GDP. The above 10\% aid mainly affects public investments.

Easterly (2001) tests the funding gap approach by reviewing the results of 88 recipient countries during the period 1965-1995. The conclusion drawn is that there is no one in Tunisia where the hypotheses associated with this method can be confirmed from an empirical point of view. To illustrate his point, he gives the example of Zambia: "If this country had transformed all the aid received since 1960 into investment and that, in turn, all this investment had been transformed into growth, it would have had a GDP per capita about twenty thousand dollars in the early 1990s. Zambia's GDP per capita was lower in the early 1990s than it was in 1960, at around five hundred dollars.

For ActionAid International (2005), two-thirds of the APD flows provided in 2003 represented "ghost aid": 20\% of the aid was invested in inefficient technical cooperation projects whose overhead costs mainly benefited donor 
country consultants. ; $14 \%$ of ODA was recorded as deleveraging measures that corresponded only to book-entry games. In addition, ODA is inflated by excessive transaction costs related to administrative and aid coordination costs; and finally, an increasing share of ODA records the reception costs of asylum seekers in industrialized countries during the first twelve months of their stay. A realistic approach to aid as an instrument or component of foreign policy is based on the assumption that any state seeks first to increase its wealth and power. The aid is then part of an interested relationship in which donors make a financial effort to conquer markets, maintain and increase their areas of influence and promote the interests of their ruling classes (Jaquet, 2006). The authors cited above have a pessimistic view of ODA. The situation may be catastrophic in poor countries without this financial assistance.

Amewoa (2008) estimated the aid-growth equation using the double least squares method applied to a panel of 46 SSA countries from 1970 to 2005. He concludes that development aid does not seem to favor economic growth in ASS. The impact of the assistance received is not significant. Nevertheless, the properties of the least-squares estimator that Amewoa uses are asymptotic to those of a classical estimator. It is clear that conventional econometric techniques such as OLS do not provide efficient estimates of such a model. The techniques of the generalized moments in the system make it possible to avoid these inconveniences.

In his book The Fatal Aid, Dambisa (2009) wonders why the majority of sub-Saharan countries are struggling in an endless cycle of corruption, disease, poverty, and dependency despite the fact that they have received more than 300 billions of dollars since 1970. His answer is that Africans are poor precisely because of this assistance. She says that between 1970 and 1998, when the aid flow was at its peak, the poverty rate in Africa had grown staggeringly. It went from $11 \%$ to $66 \%$. For Dambisa, loans on very favorable terms and subsidies (for emergency relief) have effects comparable to the possession of valuable natural resources. They encourage corruption, discourage free enterprise and cause conflict. She proposes four sources of financing "free of harmful effects": to use international bond markets by taking advantage of diminishing returns, to encourage China's infrastructure investment policy, to fight against Europe and the United States. United to develop exports of food products and raw materials and finally encourage financial intermediaries and microfinance. In the same vein, Easterly (2009) estimates that most of the aid provided over the last 50 years has been ineffective. One of the reasons would be the lack of control over the people in charge of managing them.

Camara (2010) claims that the billions of dollars that Equatorial Guinea has received over the past 25 years have been worthless. The economic challenges facing it in the aftermath of colonization remain intact and it would not be an exaggeration to signal a socio-economic decline in many areas. He adds that the culture of assistantship and ease that implies the massive use of external assistance requires a challenge to this policy doubly advocated by development partners and African states.

The comments of Camara (2010), Easterly (2009), Dambisa (2009) are certainly relevant but can be seen as compassionate discourses against ODA when we know that the development of Singapore, Taiwan, and South Korea is often cited as a success story of international aid.

Using the estimation of error correction models for short-term dynamics, Dazoue (2011) has shown that in the short and long run, aid has no significant impact on economic growth in Cameroon. The Dazoué study focuses only on Cameroon.

Eregha and al. (2012) show that aid has a negative and significant effect on growth in the ECOWAS region. For them, aid should not be seen as a means to increase growth but rather as an instrument that undermines growth in this region. In addition, there are many works for which the effectiveness of ODA is conditioned. 


\subsubsection{Conditions of effectiveness of ODA}

Work on the political economy of economic reforms (Nelson 1989 and 1990 pioneers) marked a turning point, highlighting the role of local political systems in failures and resistance to donor initiatives. Dollar and Easterly (1999) corroborate this assertion and argue that in a credible environment, aid favors private investment and that the relationship between these two variables depends on the quality of the economic policy.

Similarly, Burnside and Dollar (2000), Lensink and White (2000) as well as Collier and Dollar (2002) highlight the effectiveness of ODA. They make an interactive study of aid, politics and growth. Their studies show that aid has a positive effect on growth in a healthy political environment, whereas it is not the case in a diseased political environment. According to these authors, the effectiveness of aid depends on the quality of the economic policy of the recipient country. According to them, it is necessary to target only poor countries with sound economic policies to maximize the effectiveness of aid. The Burnside and Dollar (2000) study used a sample of 56 developing's countries for 4-year sub-periods from 1970 to 1993 . The two-stage least squares method is used to estimate the equations for these variables simultaneously. It is represented through econometric analyzes incorporating three explanatory variables of economic policy: inflation, the budget surplus and the policy of openness. The results obtained are presented as follows:

$\mathrm{POL}=1.28+6.85^{*}$ Budget surplus $-1.40^{*}$ Inflation $+2.16^{*}$ Commercial opening policy.

The variable POL is then introduced into the equation below having the dependent variable "GROWTH":

GROWTH $=-0.60$ (Initial income per capita $)+0.71($ POL $)-0.021$ (Aid / GDP $)+0.19$ (Aid / GDP) * POL + $\mathrm{gX}$ where $\mathrm{X}$ is a set of control variable.

These results reveal that the Aid / GDP explanatory variable is not significant, which means that Aid alone does not have an impact on growth. However, if we combine this explanatory variable with a policy variable Aid / $\mathrm{GDP} * \mathrm{POL}$, then it becomes very significant and, as a result, it will have a positive effect on growth.

Lensink and White (2000) as well as Collier and Dollar (2002) use the same indicators of economic policy as Burnside and Dollar (2000). Nevertheless, Collier and Dollar (2002) point out, on the one hand, that the total impact of Aid is large compared to the one suggested by the analysis of Burnside and Dollar (2000). On the other hand, they reveal that the sensitivity of aid to politics is more variable, that is a one-percentage point change in aid leads to a change in the growth rate of 0.6 percentage points in countries with good economic policies. This rate is 0.4 points for countries with medium economic policies and 0.2 for countries with weak economic policies steris paribus.

The model of previous authors has been the subject of significant criticism (Saad, 2012). The selectivity of the recipient countries on the one hand and the rather small sample of countries, on the other hand, have been called into question. In addition, the budget surplus would not be a significant determinant of growth.

Following the analysis of Burnside and Dollar, Dalgaard and al. (2001) introduced in addition to the interactive term aid with the economic policy indicator Aid * POLt, an interactive term of aid with the initial quality of these policies Aid * POL (t-1). They come to the conclusion that Aid * POLt is a significantly positive variable while Aid * POL (t-1) is significantly negative.

Devarajan and al. (2001) studied the relationship between aid and reforms in 10 African countries, including two reforming countries (Ghana and Uganda) where the impact of aid played a more than positive and significant role. However, they consider that relatively high amounts of aid directed at countries with poor economic policies tend to persist in bad policies. 
Similarly, Denkabe (2003) seeks to determine the impact of ODA on economic growth vis-à-vis economic policy. As a measure of the latter, he retained trade openness, inflation and the fiscal balance. Using the GMM, he suggests that there is an ODA threshold below which ODA tends to have a positive impact on growth but above which its effect is not positive on growth. This aid threshold is a function of macroeconomic policy. All these results have been contested in many works including those of Guillaumot and Chauvet (1999). They say that good macroeconomic policy has a positive influence on growth, regardless of aid or the external environment. They show that aid remains effective even if the quality of economic policy is not taken into account.

According to Lensink and Morrissey (2000), when the uncertainty of ODA is taken into account, its impact on growth becomes significant. They, therefore, consider a fair investment equation to show that the impact of ODA on growth is through investment, adding an uncertainty variable for ODA. To estimate the investment equation, they use the average values of 88 developing's countries, including 43 African countries between 1970 and 1995. Their result establishes that ODA has a significant impact on investment only when the uncertainty of ODA is included in the equation but remains insignificant when only African countries are considered.

In one of their publications, Guillaumot and Chauvet (2001) show that aid is more effective in countries that are economically vulnerable. Moreover adding this new variable $\mathrm{A} * \mathrm{E}$ causes the interactive term $\mathrm{A} * \mathrm{P}$ to be negative, significant when using the OLS (Ordinal Least Square) method but not significant when it is TSLS (Two Stage Least Square) techniques which are used. The authors conclude that additional aid must be given to countries facing external shocks. In addition, they believe that external factors have an impact on the policy variable so that countries vulnerable to external shocks find it very difficult to maintain sound policies.

Hansen and Tarp (2001) support the idea of Guillaumot and Chauvet (1999). Using the GMM, they state that the marginal effect of aid on productivity seems to decrease when aid flows increase. They add that there is no relationship between aid and economic policy. Like Burnside and Dollar (2000), these authors used three variables to indicate economic policy. Reading the empirical literature on the effectiveness of ODA reveals a great deal of controversy around it.

Not pretending to be a pioneer, it seemed to us necessary to deepen the analyzes by varying the components, by modifying the sample of countries and trying to solve the different econometric limits thanks to the analysis methodology (which will make subject of the next section) borrowed from Blundell and Bond (1998).

\section{METHODOLOGY OF RESEARCH}

\subsection{Study area, nature and source of data}

The estimates are conducted on a dynamic panel of twenty-three SSA's countries presented in the table below over a period from 1985 to 2014. The main reason for the exclusion of other countries from the analysis is the absence of much data. for some series only for some countries. Macroeconomic data used for econometric analysis are from secondary sources and come from the World Bank's CD-ROM (World Development Indicators, 2015). 
Table 1: Countries selected for the study

\begin{tabular}{|c|c|c|c|}
\hline Benin & Ethiopia & Mozambique & Sierra Leone \\
\hline Botswana & Gambia & Niger & Sudan \\
\hline Burkina Faso & Ghana & Nigeria & Togo \\
\hline Cameroon & Kenya & Uganda & Zambia \\
\hline Cape verde & Lesotho & Senegal & \\
\hline Ivory Coast & Mali & \multicolumn{2}{l}{} \\
\hline
\end{tabular}

Source: Authors

\subsection{Empirical model of ODA}

The importance of ODA goes back to the work of Rosenstein-Rodan (1943) with the Big Push theory which states that rapid and massive aid is the only way to eradicate poverty in the world and to enable poor countries to burn some steps prior to take-off. These calls for increased aid have had a positive impact worldwide and ODA has become the largest program of humanity. For example, the WB, the IMF, the industrialized countries of Europe and North America, Japan, to name but a few, have looked into this program. International aid is fast becoming an inseparable part of foreign policy.

Nevertheless, very early on, voices rose against the foreign aid policy, prompting many writers to question the effectiveness of foreign aid. It was then that Burnside and Dollar $(1997,2000)$ developed an aidgrowth model.

Our model is based on the work of the WB (1998) initially undertaken by Burnside and Dollar (1997, 2000) and later developed by Collier and Dollar (2002). The basic model is as follows:

$$
\mathbf{G}=\mathbf{c}+\mathbf{b}_{1} \mathbf{X}+\mathbf{b}_{2} \mathbf{P}+\mathbf{b}_{3} A+\mathbf{b}_{4} A^{2}+\mathbf{b}_{5} \mathbf{A} . \mathbf{P}
$$

In this model, $\mathrm{G}$ represents the growth of income per capita; $\mathrm{X}$ is the set of control variables that includes temporal and regional dummies; $\mathrm{P}$ is the economic policy variable and A is the aid / GDP ratio. As part of this work, G will represent the growth rate of real GDP per capita which is the most used indicator for economic growth and noted that $\mathrm{Y} . \mathrm{X}$ is still the set of control variables, it includes:

-The delayed endogenous variable of a period $\left(\mathrm{Y}_{\mathrm{i}, \mathrm{t}-1}\right)$ : it is introduced among the explanatory variables to test the effect of dynamic behaviors

-Investment (INV): These are government expenditures of a country. Khan (2006) shows that public investment is the channel through which aid has a significant and positive effect on growth in Cameroon. So this is a variable that is not least in the aid-growth relationship.

-the population (POP) makes it possible to take demographic pressure into account in explaining the growth rate (Collier and Dollar, 2002).

So,

$X=f\left(Y_{i, t-1}, I N V\right.$, POP $)$

$\mathrm{P}$ remains the political variable that will be noted $\mathrm{POL}^{3}$. For Burnside and Dollar (2000), it is measured by inflation, budget surplus and trade openness. But for the WB (1998), it is the indicator CPIA (Country Policy and

\footnotetext{
${ }^{3}$ According to Burnside and Dollar (2000), "good" economic policies are defined by controlling the rate of inflation, balancing the budget and implementing a policy of open trade. These three exogenous variables are aggregated in a composite indicator $(\mathrm{P})$ and are also weighted according to their correlation with economic growth.
} 
Institutional Assessment) which measures $\mathrm{POL}^{4}$, the political environment. We would have liked, like Collier and Dollar (2002), to use the WB index to measure POL but we are constrained by the unavailability of the data on this series because these data, in most African countries, are only available from 2004 according to the WDI (2015). We will, therefore, be satisfied with the measure of economic policy proposed by Burnside and Dollar (2000). The only difference is that we will only use inflation (INF) and trade openness (OUV) as proxies for economic policy as a simplification measure. In addition, we agree with Saad (2012) that the budget surplus would not be a significant determinant of economic growth. This surplus could still be a budget deficit for the PASS. It will, therefore, be a question of constructing the political variable from these two proxies. For this, it is first necessary to estimate as Burnside and Dollar (2000), Lensink and White (2000) the following equation:

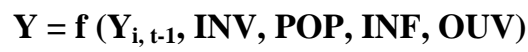

Then, the inflation rate and the trade opening are aggregated in a composite indicator according to their weightings with the economic growth so that we will have the economic policy variable

POL $=\mathbf{a}_{0}+\mathbf{a}_{1}$ INF $+\mathbf{a}_{2}$ OUV.

$\mathrm{A}$ is the ODA / GDP ratio in the base model. In this model, A is the amount of ODA. The term ODA ${ }^{2}$ will be maintained to determine the marginal effect of the aid on growth. It is the equation

$\mathbf{Y}_{\mathrm{a}}=\mathbf{b}_{\mathbf{3}}+\mathbf{2} \mathbf{b}_{\mathbf{4}} \mathrm{ODA}+\mathbf{b}_{\mathbf{5}} \mathbf{P O L}$ obtained by deriving the basic equation (1.1) with respect to the ODA;

$\mathrm{ODA}^{2}$ is also introduced to take into account the possibility of non-linearity of the relationship between aid and economic growth, theoretically founded by the law of decreasing the productivity of capital.

Burnside and Dollar (2000) hypothesize that aid effectiveness is conditioned by economic policy, hence the introduction of the interactive term ODA*POL to test this hypothesis.

Since this study is inspired by Burnside and Dollar (2000), the interactive term ODA*POL is also preserved in the equation to be estimated in order to verify whether aid is conditional on economic policy. The equation can be rewritten as follows

$$
Y_{i t}=b_{0}+b_{1} Y_{i, t-1}+b_{2} I N V_{i t}+b_{3} P O P_{i t}+b_{4} O U V_{i t}+b_{5} I N F_{i t}+b_{6} O D A_{i t}+b_{7} O D A_{i t}^{2}+b_{8} O D A_{i t} * P O L_{i t}+\varepsilon_{i t}(1.4)
$$

The dynamic equation to estimate is as follows:

$$
Y_{i t}=b_{0}+b_{1} Y_{i, t-1}+b_{2} I N V_{i t}+b_{3} P O P_{i t}+b_{4} O U V_{i t}+b_{5} I N F_{i t}+b_{6} O D A_{i t}+b_{7} O D A_{i t}^{2}+b_{8} O D A_{i t} * P O L_{i t}+e_{i}+\varepsilon_{i t}
$$

$e_{i}$ is the invisible specific effect for each country $i$ and $\varepsilon_{i t}$ is the error correction term. The real GDP per capita growth rate is the endogenous or explained variable of the model, the exogenous or explanatory variables are the following: ODA, OUV, INF, INV, POP, ODA ${ }^{2}$, ODA.POL and $\mathrm{Y}_{\mathrm{i}, \mathrm{t}-1}$. The expected results are summarized in the table below:

Table 2 : Expected Signs of the ODA - Economic Growth Equation

\begin{tabular}{|c|c|}
\hline Exogenous Variables & Expected Signs \\
\hline ODA & $(+)$ \\
\hline OUV & $(+)$ \\
\hline INF & $(+/-)$ \\
\hline INV & $(+)$ \\
\hline POP & $(-)$ \\
\hline
\end{tabular}

\footnotetext{
${ }^{4}$ PASSs are strongly similar in many respects (economic, political, historical, geographical, cultural). This would minimize the effect of not ranking these countries in countries with good policies or countries with bad policies.
} 


\begin{tabular}{|c|c|}
\hline $\mathrm{Y}_{\mathrm{i}, \mathrm{t}-1}$ & $(-)$ \\
\hline ODA $^{2}$ & $(-)$ \\
\hline ODAxPOL & $(-)$ \\
\hline
\end{tabular}

\subsection{Analysis method}

To estimate the dynamic equations above, the Generalized Method of Moments (GMM) from Blundel and Bond (1998) system is used. The GMM system estimator combines the first difference equations with the level equations. The instruments in the equation in first differences are expressed in level and vice versa as we will have to do to the system below:

$$
\left\{\begin{array}{c}
\Delta y_{i, \mathrm{t}}=\beta \Delta y_{\mathrm{i}, \mathrm{t}-1}+\varphi \Delta X_{\mathrm{i}, \mathrm{t}}+\Delta v_{\mathrm{t}}+\Delta \varepsilon_{\mathrm{i}, \mathrm{t}} \\
y_{\mathrm{i}, \mathrm{t}}=\beta y_{\mathrm{i}, \mathrm{t}-1}+\varphi X_{\mathrm{i}, \mathrm{t}}+v_{\mathrm{t}}+\varepsilon_{\mathrm{i}, \mathrm{t}}
\end{array}\right.
$$

This assumes that the equation to be estimated will be rewritten as a system when analyzing the data. The GMM system of Blundel and Bond (1998) provides solutions to the problems of simultaneity, endogeneity, inverse causality and omitted variables.

This method exploits the variation of time series data, takes into account the specific effects that are invisible to each country and allows the inclusion of delayed dependent variables as exogenous variables. To the detriment of the first difference GMM estimator of Arellano and Bond ${ }^{5}$ (1991) and the usual methods such as OLS, instrumental variables, the GMM system estimator of Blundel and Bond (1998) was favored because these two authors have shown using Monte Carlo simulations that the GMM estimator in the system is more efficient than the first difference one. The GMM first difference estimator gives biased results in the finished samples when the instruments are weak or when persistent variables are present. The bias affecting the Arellano and Bond estimator (1991) and leading to an underestimation of the autoregressive coefficient would be according to Blundel and Bond (1998), corrected by the system estimation. Moreover, with the usual methods, country-specific fixed effects are not taken into consideration.

To test the validity of delayed variables as instruments, Arellano and Bond (1991), Arellano and Bover (1995) and Blundel and Bond (1998) suggest the Sargan overidentification test and the second order autocorrelation test.

The use of the dynamic panel GMM estimator ${ }^{6}$ presupposes the quasi-stationarity of the variables of the level equation and the absence of autocorrelation of the residuals. For this, we will first make the stationarity test on the series to detect if there is presence of unit roots using the test of Im Pesaran and Shin. The Augmented Dickey Fuller (ADF) test can no longer be used because if the number of delays is overestimated, the power of

\footnotetext{
${ }^{5}$ The procedure of Arellano and Bond (1991) consists in rewriting the initial equation in first difference, which eliminates the individual fixed effects, and then using as their instruments for differentiated series their own delayed levels. This method improves instrumental variables estimation of Anderson and Hsiao (1982) by referring to a set of orthogonality conditions defining optimal GMM estimators. It solves, moreover, the delicate choice concerning the list of instruments.

${ }^{6}$ A dynamic model is a model in which one or more lags of dependant variable are included as explanatory variables. In contrast to the GMM in dynamic panel, standards econometric technical as well as OLS does not allow one to obtain efficient estimates for such model because of the presence of the lagged dependant variable to the right of the equation.
} 
the ADF test is deteriorated. The problem is fundamental if the number of delays is undervalued. In this case, the model's parametrization does not fully whiten the residues, which is why the asymptotic distributions of DFA are no longer valid (Hurlin and Mignon, 2005).

The first unit root tests on heterogeneous panels were proposed by Im Pesaran and Shin (1997), Maddala and Wu (1999), Breitung (2000) and Levin and Lin Chu (2002). These authors propose a simple test statistic based on the average of individual ADF statistics. One of the main weaknesses of the Breitung (2000) and Levin and Lin (2002) tests is the homogeneity of the autoregressive root under the alternative hypothesis. In other words, for these authors, in a given panel of countries for example, these countries behave in a homogeneous way, which is problematic in reality. Under the alternative hypothesis H1, the Im Pesaran and Shin (1997) (IPS) tests allow not only a heterogeneity of the autoregressive root, but also a heterogeneity as to the very presence of a unit root in the panel. The authors introduce a test under the name of t-bar and propose to test the null hypothesis $\varphi \mathrm{i}=0$ for all values of $\mathrm{i}$ against the alternative hypothesis $\varphi \mathrm{i}<0$ for $\mathrm{i}=1,2, \ldots . ., \mathrm{N} 1$ and $\varphi \mathrm{i}=$ 0 for $\mathrm{i}=\mathrm{N} 1+1, \mathrm{~N} 2+2, \ldots \ldots ., \mathrm{N}$.

In Pesaran and Shin (2003) demonstrated by Monte Carlo simulation that their own test has a stronger explanatory power than the other panel unit root tests. We, therefore, favor this test for all these reasons.

If the series are not stationary, ie if there is a unit root, Pedroni's $(1999,2004)$ tests will be used to test for the presence of a cointegration relationship between growth and exogenous variables to the detriment of Engle and Granger tests (1987).

\subsection{Results and interpretation of the ODA-economic growth model}

\subsubsection{Result of the Stationarity test of the ODA - growth equation}

Table 3: Im-Pesaran-Shin unit root test result of the ODA - growth equation

\begin{tabular}{|c|c|c|c|c|c|}
\hline \multirow{3}{*}{ Series } & \multicolumn{5}{|c|}{ Stationarity Test at Level } \\
\hline & \multicolumn{2}{|c|}{ With constant } & \multicolumn{2}{|c|}{ With constant and trend } & \multirow[t]{2}{*}{ Decisions } \\
\hline & t-stat & P-value & t-stat & P-value & \\
\hline $\mathrm{Y}$ & $-22,648 * * *$ & 0,0000 & $-22,642 * * *$ & 0,0000 & Stationary \\
\hline ODA & $-7,3 * * *$ & 0,0000 & $-7,298 * * *$ & 0,0000 & Stationary \\
\hline OUV & $-4,695 * * *$ & 0,0001 & $-4,702 * * *$ & 0,0007 & Stationary \\
\hline INF & $-8,481 * * *$ & 0,0000 & $-8,801 * * *$ & 0,0000 & Stationary \\
\hline POP & $-3,935 * * *$ & 0,0019 & $-3,948 * *$ & 0,0108 & Stationary \\
\hline INV & $-5,574 * * *$ & 0,0000 & $-5,600 * * *$ & 0,0000 & Stationary \\
\hline ODAxODA & $-10,514 * * *$ & 0,0000 & $-10,521 * * *$ & 0,0000 & Stationary \\
\hline $\begin{array}{l}\text { Im Pesaran and } \\
\text { Shin statistic }\end{array}$ & $28,950 * * *$ & 0,0000 & $28,833 * * *$ & 0,0000 & $\begin{array}{l}\text { Absence of } \\
\text { common unit root }\end{array}$ \\
\hline
\end{tabular}

Notes: Stationary panel data at $* * * 1 \%, * * 5 \%, * 10 \%$.

\section{Assumptions of the IPS test}

-H0: Absence of unit root

-H1: presence of unit root

Decision rule: If the probability associated with each series is lower than the different critical thresholds $(1 \%$, $5 \%$ and $10 \%$ ), then there is no unit root. So we accept the hypothesis H0 to the detriment of the alternative hypothesis H1. 
Given the table above, it is clear that the P-value of all the series after stationarity tests ${ }^{7}$ (with constant and with constant and trend) are lower, either at $1 \%$ or $5 \%$. We therefore conclude that all the series are stationary at level.

In addition, the statistics of Im Pesaran and Shin also have a lower probability than the various thresholds, which means that there is no common unit root. So the Pedroni cointegration test will not be necessary in this case. Thus, we can go directly to the estimates without the risk of fallacious regression.

\subsubsection{Results of estimates of the ODA - growth equation}

Table 4 : Results of the estimation of the ODA equation and economic growth

\begin{tabular}{|c|c|c|c|c|}
\hline Column 1 & Column 2 & Column 3 & Column 4 & Column 5 \\
\hline Method: GMM system & $\begin{array}{l}\text { Estimation with } \\
\text { control variables } \\
\text { only }\end{array}$ & $\begin{array}{l}\text { Introduction of } \\
\text { ODA }\end{array}$ & $\begin{array}{l}\text { Introduction of } \\
\mathrm{ODA}^{2}\end{array}$ & $\begin{array}{l}\text { Introduction of } \\
\text { the interactive } \\
\text { term :ODAxPOL }\end{array}$ \\
\hline Explanatory variables & $\begin{array}{l}\text { Coefficients } \\
\text { (p-value) }\end{array}$ & $\begin{array}{l}\text { Coefficients } \\
\text { (p-value) }\end{array}$ & $\begin{array}{l}\text { Coefficients } \\
\text { (p-value) }\end{array}$ & $\begin{array}{l}\text { Coefficients } \\
\text { (p-value) }\end{array}$ \\
\hline Constant & $\begin{array}{l}-10,386^{* * * *} \\
(0,002)\end{array}$ & $\begin{array}{l}-13,598 * * * \\
(0,001)\end{array}$ & $\begin{array}{l}-30,778 * * * \\
(0,000)\end{array}$ & $\begin{array}{l}-36,182 * * * \\
(0,000)\end{array}$ \\
\hline$Y_{i, t-1}$ & $\begin{array}{l}0,0907 * * \\
(0,020)\end{array}$ & $\begin{array}{l}0,082 * * \\
(0,036)\end{array}$ & $\begin{array}{l}0,0263 \\
(0,463)\end{array}$ & $\begin{array}{l}-0,00475 \\
(0,893)\end{array}$ \\
\hline Investment (INV) & $\begin{array}{l}1,115 * * * \\
(0,000)\end{array}$ & $\begin{array}{l}1,383 * * * \\
(0,000)\end{array}$ & $\begin{array}{l}2,002 * * * \\
(0,000)\end{array}$ & $\begin{array}{l}2,066 * * * \\
(0,000)\end{array}$ \\
\hline Population (POP) & $\begin{array}{l}-0,701 * * * \\
(0,008)\end{array}$ & $\begin{array}{l}-0,858 * * * \\
(0,001)\end{array}$ & $\begin{array}{l}-0,806 * * * \\
(0,001)\end{array}$ & $\begin{array}{l}-0,799 * * * \\
(0,001)\end{array}$ \\
\hline Trade opening (OUV) & $\begin{array}{l}0,357 \\
(0,607)\end{array}$ & $\begin{array}{l}0,200 \\
(0,779)\end{array}$ & $\begin{array}{l}1,332 * * \\
(0,046)\end{array}$ & $\begin{array}{l}5,385 * * * \\
(0,000)\end{array}$ \\
\hline Inflation rate (INF) & $\begin{array}{l}0,0408 \\
(0,617)\end{array}$ & $\begin{array}{l}0,0045 \\
(0,596)\end{array}$ & $\begin{array}{l}-0,00835 \\
(0,457)\end{array}$ & $\begin{array}{l}0,0594 * * * \\
(0,000)\end{array}$ \\
\hline ODA & & $\begin{array}{l}0,0291 \\
(0,209)\end{array}$ & $\begin{array}{l}\mathbf{0 , 4 0 7} * * * \\
(\mathbf{0 , 0 0 0 )}\end{array}$ & $\begin{array}{l}\mathbf{- 8 , 9 2 8} * * * \\
(0,000)\end{array}$ \\
\hline ODA $^{2}$ & & & $\begin{array}{l}-\mathbf{0 , 0 0 5 4} * * * \\
(\mathbf{0 , 0 0 0 )}\end{array}$ & $\begin{array}{l}-\mathbf{0 , 0 0 6 8} * * * \\
(0,000)\end{array}$ \\
\hline ODAxPOL & & & & $\begin{array}{l}-\mathbf{0 , 9 3 1} * * * \\
(0,000)\end{array}$ \\
\hline $\begin{array}{l}\text { Arellano and Bond Test } \\
\text { AR(1) } \\
\text { AR(2) }\end{array}$ & $\begin{array}{l}z=-2,34 \\
(0,019) \\
z=-0,18 \\
(0,854)\end{array}$ & $\begin{array}{l}z=-4,22 \\
(0,000) \\
z=-0,29 \\
(0,769)\end{array}$ & $\begin{array}{l}z=-9,34 \\
(0,000) \\
z=-0,94 \\
(0,349)\end{array}$ & $\begin{array}{l}z=-2,37 \\
(0,018) \\
z=-0,55 \\
(0,581)\end{array}$ \\
\hline Sargan Test & Chi2 $=398,06$ & Chi2 $=388,36$ & Chi2 $=400,77$ & Chi2 $=407,95$ \\
\hline
\end{tabular}

\footnotetext{
${ }^{7}$ The purpose of making the stationarity test with consistency is to be able to perceive the effects of factors other than time on the evolution of the series. Stationarity with constancy and trend includes the effects of all variables including time on the evolution of the series considered. However, stationary series with constancy are preferable than those with constant and trend because when the trend has no influence on the series, it is easier to perceive the effects of other variables other than time on the evolution of series. The effect of the trend can cover the perception of the influence of the other variables on the series.
} 
IRA-International Journal of Management \& Social Sciences

\begin{tabular}{|l|l|l|l|l|}
\hline & $(0,447)$ & $(0,528)$ & $(0,317)$ & $(0,256)$ \\
\hline Wald's statistics & Chi2 $=39,78$ & Chi2 $=45,88$ & Chi2 = 117,10 & Chi2 $=188,53$ \\
& $(0,000)$ & $(0,000)$ & $(0,000)$ & $(0,000)$ \\
\hline
\end{tabular}

Source: Author's estimates

NB: * significant variable at $10 \%$;

** Significant variable at $5 \%$;

*** Significant variable at $1 \%$;

The values in parentheses are the p-values or probabilities of the coefficients

We estimated four equations: the first estimate is a regression on the control variables; in the second, ODA is introduced; then the squared ODA at the third estimate and finally the interactive term ODA x Economic Policy at the last regression. The interpretation is made equation after equation. In the regression on control variables, the results (column 2) reveal that only investment, population size and lagged dependant variable are statistically significant. The others (inflation rate, trade opening) are not, but all have expected signs. This estimate builds the Economic Policy variable composed of trade openness and the inflation rate. These two variables are aggregated in the composite indicator policy and are also weighted according to their correlation with economic growth according to Burnside and Dollar (2000). Thus, our political variable is: POL $=-10,386+$ 0,357 OUV $+0,0408$ TIN $^{8}$.

The introduction of ODA (column 3) in the estimate does not change much from the previous one. The significant variables of the first estimate are the same to be. No variable changes sign. Looking at the main variable of this regression (ODA), we note that its impact on growth is not significant although it has a positive sign. This means that aid alone is not a decisive variable in promoting economic growth in SSA. Its volume still seems negligible to significantly boost growth. These findings are consistent with those of Barro (1990) and Amewoa (2008).

When the aid squared $\left(\mathrm{ODA}^{2}\right)$ is entered in the estimate (column 4), the ODA becomes significant, that is, a substantial amount of assistance be effective in raising the economic growth rate of the SSA countries. However, ODA squared $\left(\mathrm{ODA}^{2}\right)$ is also significant and negative. This would mean that the aid-growth relationship is a non-linear relationship. The negative sign of $\mathrm{ODA}^{2}$ confirms the decreasing marginal yield assumption of aid. As a result, aid has a positive and significant impact on economic growth up to a certain amount called the critical threshold. When aid exceeds this threshold, its effect on growth becomes negative and is in line with the Laffer Curve or Kuznets Environmental Equation. The same results were obtained by Hansen and Tarp (2001), Dalgaard and Hansen (2000), Burnside and Dollar (2000). This is what Lensink and White (2001) have called "Aid Laffer Curve".

The point of return at which the aid changes direction is set at $15 \%$ of GDP of beneficiary countries according to Burnside and Dollar (2000), at 20\% of GDP for Dalgaard and Hansen (2000), at 25\% of GDP per capita. Hansen and Tarp (2001) and at 30\% of GDP by Collier and Dollar. For Amewoa (2008), the threshold above which any increase in aid would become counterproductive would then be $30.54 \%$ of GDP, while

\footnotetext{
${ }^{8}$ According to Burnside and Dollar (2000), Lensink and White (2000), "good" economic policies are defined by controlling the rate of inflation, balancing the budget and implementing a policy of open trade. These three exogenous variables are aggregated in a composite indicator $(\mathrm{P})$ and are also weighted according to their correlation with economic growth. In our table of results (column 2), 0.357 was obtained as the coefficient of trade openness and 0.0408 as inflation, then -10.386 for the constant from which the economic policy equation $\mathrm{POL}=-10,386+0,357$ OUV $+0,0408 \mathrm{TIN}$. Burnside and Dollar (2000) obtained the policy equation $=1.28+6.85$ Budget Surplus -1.4 Inflation +2.16 Openness.
} 
Durbarry et al. (1998) identify it at 40\%. Lensink and White $(1999,2001)$ in their estimates find that the threshold at which aid yields become negative is between $40 \%$ and $50 \%$ of the recipient country's income.

This study suggests that in SSA, this threshold above which aid starts to have perverse effects on growth could be estimated at $75 \%$ of the $\mathrm{GDP}^{9}$ of these countries. There would be a parabolic or bell-shaped relationship (U-reversed) between aid and economic growth. We have the following case:

Chart 1: Optimal ODA

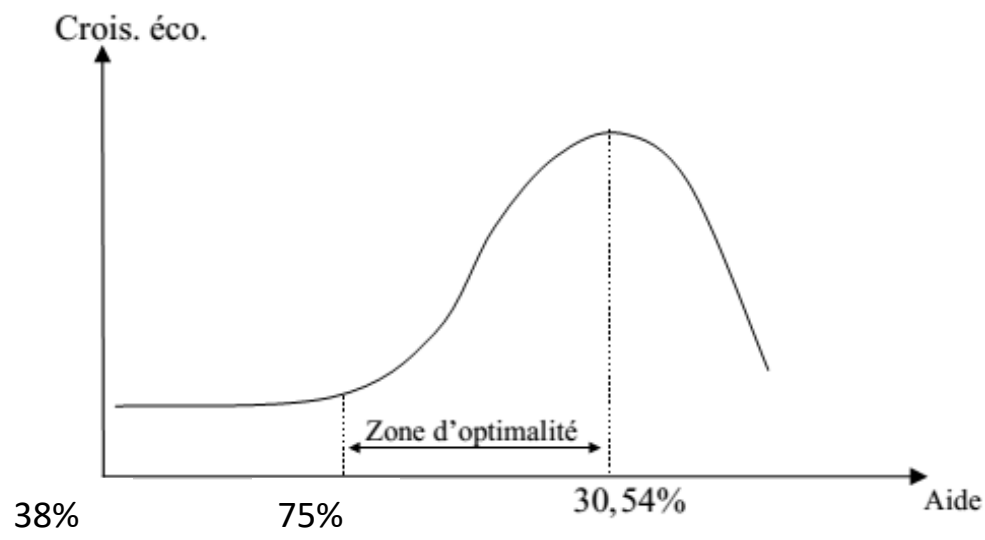

Source: Made by the authors

The regression made on all the variables including the interactive term (ODA $x$ Policy) gives the very different results (column 5). The taking into account the interactive term in the estimation improves the significance of all the variables with the exception of initial income per capita that is not significant. The variable ODAxPOL is itself statistically significant, which means that the effectiveness of ODA is conditioned by the quality of economic policy in the recipient countries.

Nevertheless, the introduction of this interactive term has made the ODA coefficient negative, contrary to the sign obtained in previous estimates. In addition, the interactive variable also has a negative coefficient. All of this reflects the fact that economic policy seems to be bad in the PASS, which has a negative effect of aid on economic growth. This result is consistent with those found by Burnside and Dollar (2000), Collier and Dollar (2002) for whom the impact of aid is negative in countries with poor economic policies. The explanation that can be made is that massive assistance to the SSA countries could be used to expand government bureaucracies, perpetrate bad governance or enrich the elite at the expense of sound policies inflation rate, implementation of a policy of adequate trade openness, creation of industries or encouragement of local production). In this last estimate, the squared help variable keeps its negative sign, which is in line with the result found previously and reinforces the assertion that the marginal effectiveness of the aid decreases as its volume increases. Thus, marginal economic growth $\left(\mathrm{Y}_{\mathrm{a}}\right)$ in relation to aid corresponds to the following equation:

\footnotetext{
${ }^{9}$ In general, the equation curve $y=-a x^{2}+b x+c$ has a unique vertex given by $S=b / a$. According to column 4 of the results table, there is a relationship between the economic growth rate $(y)$ and the aid as a percentage of GDP (ODA), the following relationship: $y=-0.0054$ ODA $^{2}+0.407$ ODA + $c$ with $c$, a constant. From this we deduce the maximum aid threshold at $S=b / a=0.407 / 0.0054=75 \%$. Similarly, to have the minimum threshold necessary for the ODA to begin to be productive, it is sufficient if the derivative of the above equation with respect to the ODA is zero. We get $2 x(-0.0054) A P D+0.407=0 \leftrightarrow A P D=0.407 / 0.0108=37.68$ $\approx 38 \%$.
} 
$Y_{\mathrm{a}}=-8,928-0.0136$ ODA - 0.931 POL

The investment variable is the only variable to be positive and statistically significant in the four regressions. So, this variable is unavoidable in the aid-growth relationship. This is the channel through which aid could positively and significantly affect economic growth, ie the volumes of aid received by SSA countries should be used for both public and private investment.

With respect to the initial income, the convergence hypothesis assumes a negative effect of its coefficient. For the last estimate, this assumption is confirmed although the initial endowment is not significant.

As regards the trade openness and inflation variables, they become statistically significant in the last regression, which shows that economic policy is essential in the aid-economic growth relationship.

\section{4- CONCLUSION}

At the end of this study, it is clear that SSA has been the main recipient region of global aid for several years. However, poverty is on the rise in this region because the rate of growth it records is still insufficient to eradicate it. To elucidate this paradox, an econometric study on the impact of ODA on economic growth in SSA was undertaken. To do so, twenty-three countries were selected over a period from 1985 to 2014. Using the GMM system from Blundel and Bond (1998) based on dynamic panel data, the following conclusions were drawn: Aid alone can not promote economic growth in SSA because its volume is still very low. If the amount of ODA increases significantly, its effect on the GDP per capita would be significant. Nevertheless, it must not go beyond a certain amount that could be set at $75 \%$ of the GDP of the recipient countries. Exceeding this threshold, aid becomes harmful for economic growth. Nevertheless, it is clear from this analysis that the effectiveness of ODA is conditioned by the quality of the economic policy. This seems to be bad in SSA, hence the negative impact of the aid on economic growth.

\section{BIBLIOGRAPHY}

[1] ActionAid International, (2005); Real aid: An agenda for making aid work, London :ActionAid. http : //www.actionaid.org.uk/doc_lib/69_1_real_aid.pdf.

[2] Amewoa K., (2008);L'Aide au développement aide t'elle le développement? Le cas de l'Afrique Subsaharienne, thèse de doctorat ès Sciences Economiques, Limoges.

[3] BanqueMondiale, (1998); «Assessing Aid: What works, What Doesn't, and Why? , Oxford University Press, Washington DC, World Bank.

[4] Barro R., (1990); Government spending in a simple model of endogenous growth, the journal of political economy, vol. 98, $\mathrm{N}_{0}$. 5, Part 2: the problem of development. A conference of the Institute for the study of free enterprise systems.

[5] Berg E., (1997); Dilemmas in Donor Aid Strategies, Mimeo, Workshop of External Resources for Development, Netherlands Economic Institute.

[6] Boone P., (1996); Politics and the Effectiveness of Foreign Aid , European Economic Review, vol. 40, $\mathrm{N}_{0} .2$, pp 289-329.

[7] Burnside C. et Dollar D., (1997); Aid, Policies, and Growth, World Bank Policy Research working paper, vol. 1777, pp 1-52.

[8] Burnside C. et Dollar D., (2000); Aid, Policies, and Growth, American Economic Review, vol. 90, $\mathrm{N}_{0} .4$, pp 847-868.

[9] Burnside C. et Dollar D., (2004); Aid, Policies, and Growth, revisiting the evidence, World Bank Policy Research paper, vol. 3251, pp 1-36.

[10] Charnoz O. et Severino J-M., (2007) ; L'aide publique au développement, Paris, Editions La Découverte, 122 p.

[11] Collier P. et Dollar D., (2002); Aid Allocation and Poverty Reduction, European Economic, Review, vol. 46, 
No. 8.

[12] Dalgaard C-J. et Hansen H., (2001); On Aid, Growth and Good Policies, Journal of Development Studies 37 , pp 17-41.

[13] Dambisa M., (2009);L'aide fatale : Les ravages d'une aide inutile et de nouvelles solutions pour l'Afrique , éditions JC Lattès.

[14] Dazoue G., (2011) ; impact de l'aide publique au développement sur la croissance économique et la réduction de la pauvreté au Cameroun, Thèse de Master, université de Dschang.

[15] Denkabe P., (2003); Policy, Aid and Growth : A Threshold Hypothesis, Department of Economics, New York university, December.

[16] Devarajan S., Miller M. et Swanson E., (2002); Goals for development : history, prospects and costs . Policy research working paper, 2819, Banque mondiale, 38 p, avril.

[17] Dollar D. et Easterly W., (1999); The Search for the Key: Aid, Investment and Policies in Africa, Journal of African Economies, vol. 8, $\mathrm{N}_{0}$. 4, pp 546-477.

[18] Easterly W., (1999); The ghost of financing gap : testing the growth model of the international financial institutions, Journal of Development Economics, vol. 2, $\mathrm{N}_{0}$. 60, pp 423-438, December.

[19] Easterly W., (2001); The Elusive Quest for Growth : Economists' Adventures and Misadventures in the Tropics, Cambridge : The MIT Press, $342 \mathrm{p}$.

[20] Easterly W., (2005); How to Assess the Needs for Aid ? The Answer: Don't Ask , Paper presented in the Third AFD/EUDN Conference, Paris.

[21] Easterly W., (2009); Le fardeau de l'homme blanc : l'échec des politiques occidentales d'aide aux pauvres , éditions Markus Haller.

[22] Eregha P., Sede P. et Ibidapo C., (2012); Foreign aid flows, investment and economic growth in Africa : Does uncertainty matter?, African Journal of Social Sciences, vol. 2, $\mathrm{N}_{0} .2$, pp 100-107.

[23] Fielding D., McGillivray M. et Torres S., (2006); Synergies between Health, Wealth, Education, Fertility and Aid: Implications for Achieving the Millennium Development Goals, UNU-WIDER, mimeo, Helsinki.

[24] Friedman M., (1958); Foreign Economic Aid, Yale Review, vol. 47, N .4 , pp 501-516.

[25] Gabas J-J. et Sindzingré A., (1996);Les enjeux de l'aide dans un contexte de mondialisation, COBEA, université de Paris-Sud.

[26] Gomanee K., Girma S. et Morrissey O., (2002); Aid, investment and growth in Sub-Saharan Africa, School of Economics, University of Nottingham.

[27] Guillaumont P. et Chauvet L., (1999); Aid and Performance : A Reassessment, Mimeo, Université d'Auvergne, CERDI, Juin.

[28] Guillaumont P. et Chauvet L.,(2001); Aid and Performance: A Reassessment, Journal of Development Studies, vol. $37, \mathrm{~N}_{0} .6$.

[29] Guloba N., Kilimani N. et Nabiddo W., (2010); Impact of China-Africa Aid Relations: A Case Study of Uganda, Final report submitted to the African Economic Research Consortium, may.

[30] Hansen H. et Tarp F., (2001); Aid and Growth Regressions, Journal of Development Economics, vol. 64, $\mathrm{N}_{0}$. 2.

[31] Hayter T., (1971); Aid as imperialism, Harmondsworth : Penguin Books.

[32] Jaquet P., (2006) ; Les enjeux de l'aide publique au développement, Politique étrangère, vol. 4, pp 941-954.

[33] Jepma C., (1991); The Tying of Aid , Paris, OECD, Development Center.

[34] Jepma C., (1996); The Case for Aid Untying in OECD Countries , in Olav Stokke (eds.), Foreign Aid towards the Year 2000: Experiences and Challenges, London, Frank Cass, Eadi Book Series 18.

[35] Joannidis M., (2010) ; Aide publique au développement : une nécessité critiquée , article, juin.

[36] Lensink R. et Morrissey O., (2000); Aid instability as a measure of uncertainty and the positive impact of aid on growth , Journal of Development Studies, vol. 36.

[37] Lensink R. et White H., (2000);Assessing Aid: A Manifesto for Aid in the $21^{\text {st }}$ Century? External Fellow of Credit, University of Nottingham.

[38] Lensink R. et White H., (2001);Are there negative returns to Aid? , Journal of Development Studies, vol. 37 , $\mathrm{N}_{0}$. 6, pp 42-46.

[39] Moreira S., (2005);Evaluating the impact of foreign aid on economic growth: A cross-country study, College of Business Administration Setubal Polytechnic.

[40] Mosley P., (1996); The Failure of Aid and Adjustment Policies in Sub-Saharan Africa: Counterexamples and Policy Proposals, Journal of African Economies, vol. 5, $\mathrm{N}_{0}$. 3, pp. 406-443, October. 
[41] Munzele J-M., (2004) ; L'aide au développement est-elle une thérapie pour l'Afrique ?, Article publié dans la revue MUNGAZI, $\mathrm{N}_{0} .13$, pp 11-16.

[42] Nafiou M., (2009) ; Impact de l'aide publique au développement sur la croissance économique du Niger, Revue africaine de l'intégration, vol 3. $\mathrm{N}_{0}$. 2, octobre.

[43] Nyoni T., (1997); Foreign aid and economic performance in Tanzania , AERC Working Paper No 61, Nairobi.

[44] Papanek G., (1972); The effect of aid and other resource transfers on savings and growth in less developed economies , Journal of Political Economy, vol. 82, pp 120-30 et 163-191.

[45] Papanek G., (1973); Aid, foreign private investment, savings, and growth in less developed countries, Journal of Political Economy, vol. 81, $\mathrm{N}_{0} .1$, pp 120-130.

[46] Ridell R., (1987); Foreign Aid Reconsidered, ODI, the Johns Hapkins University Press, James Currey.

[47] Rosenstein-Rodan P., (1943); Problems of Industrialization of Eastern and South Eastern Europe, the Economic Journal, $53 \mathrm{p}$.

[48] Saad M., (2012); Quelle efficacité de l'Aide Publique au Développement ? le cas du Ghana, Mémoire de Master 1, Université du Sud Toulon Var.

[49] Sachs JD., (2005); The end of the poverty, book review, juin.

[50] Severino J-M. et Ray O., (2010) ; Le temps de l'Afrique, essai publié aux éditions Odile Jacob.

[51] Severino J-M. et Debrat J M., (2010) ;L'aide au développement, livre publié aux éditions le Cavalier bleu.

[52] Tarp F., (2009); Aid effectiveness , UNU-WIDER.

[53] Treillet S., (2003), Le refus du développement : réflexions sur la logique d'un courant de pensée, IUFM Créteil. 